\title{
Cardosoa, a new genus of the subtribe Anisopappinae (Athroismeae, Asteraceae)
}

\author{
by \\ Santiago Ortiz \\ Laboratorio de Botánica, Facultade de Farmacia, Universidade de Santiago, 15782 Santiago de Compostela, Galicia, Spain \\ santiago.ortiz@usc.es
}

\begin{abstract}
Ortiz, S. 2010. Cardosoa, a new genus of the subtribe Anisopappinae (Athroismeae, Asteraceae). Anales Jard. Bot. Madrid. 67(1): 7-11.

The new genus Cardosoa of the subtribe Anisopappinae (Athroismeae, Asteraceae) is described for the species Anisopappus athanasioides from the Angola Plateau. The diagnostic morphological characteristics of the new genus are discussed, and contrasted to those in Anisopappus its putative sister genus. The main distinguishing features of Cardosoa in Athroismeae are its inflorescence morphology, the bilabiate marginal florets, and shallowly zygomorphic disc florets.
\end{abstract}

Keywords: Asteridae, Compositae, Tropical Africa, Angola, Huambo, systematics, taxonomy, morphology.

\section{Introduction}

In 1995 Ortiz \& Paiva described the species Anisopappus athanasioides (Asteraceae) from somewhat immature material collected by $\mathrm{H}$. Cardoso in Chianga (Huambo), on the Angola Plateau. Eldenäs \& Anderberg (1996: 174) considered the specimen from which it was described to be "significantly different from all other species of Anisopappus". We subsequently found more complete material of this taxon and discovered that, besides its distinct capitula and inflorescence, it has bilabiate (i.e. with one adaxial and three abaxial lobes) marginal florets when mature, very different to those of Anisopappus Hook \& Arn., which always are true ray florets. In view of these and other very marked morphological differences with respect to Anisopappus and other related members of the Asteraceae, we describe a new genus for this species.

\section{Resumen}

Ortiz, S. 2010. Cardosoa, un nuevo género de la subtribu Anisopappinae (Athroismeae, Asteraceae). Anales Jard. Bot. Madrid. 67(1): 7-11 (en inglés).

Se describe el nuevo género Cardosoa de la subtribu Anisopappinae (Athroismeae, Asteraceae) para la especie Anisopappus athanasioides del planalto de Angola. Se discuten los caracteres morfológicos más distintivos del nuevo género, especialmente frente a Anisopappus. Los caracteres morfológicos de mayor valor diagnóstico son el tipo de inflorescencia y la presencia en Cardosoa de flores marginales bilabiadas y flores del disco zigomorfas en mayor o menor medida.

Palabras clave: Asteridae, Compositae, África tropical, Angola, Huambo, sistemática, taxonomía, morfología.

\section{Material and methods}

Morphological characters were studied in herbarium specimens of the 18 species of Anisopappus (including $A$. athanasioides) from BM, COI, K, LISC, LISE, LISU, LUA, LUAI, P and PRE.

Macromorphological characters were studied with the aid of a light microscope. For microscopic examination of floral parts, these were first boiled in water with a surfactant, and subsequently mounted in Hoyer's solution (Anderson, 1954). Cypsela sections were cut by hand with razor blades. Micromorphological and anatomical characters were studied with a compound light microscope.

For examination of corolla and cypsela features, florets were mounted on aluminium stubs and coated with a c. 30-nm gold layer for study with a LEO 435VP scanning electron microscope (SEM) operating at $15 \mathrm{kV}$. 


\section{Description}

Cardosoa S. Ortiz \& Paiva, gen. nov.

Type species: Cardosoa athanasioides (Paiva \& S. Ortiz) S. Ortiz \& Paiva, comb. nov. - Anisopappus athanasioides Paiva \& S. Ortiz in Bot. J. Linn. Soc. 117: 40 (1995) (Basion.). TYPE: Angola, Huambo district, Huambo, Chianga, 1700 m, 10 May 1965, wasteland and grassy areas, Helder Cardoso s.n. (COI, holotypus).

A genere Anisopappus differt capitulis racemosis, floribus marginalibus capituli uniuscuisque bilabiatis limbo quidem abaxiali $1.5-2 \mathrm{~mm}$ longo nerviisque lobulorum usque ad basin divisis - floribusque centralibus plus minusve zygomorphis ob lobulorum corollinorum inaequalem satis incisionem.

Subshrubs. Stems terete, without resin canals, herbaceous parts with multiseptate hairs. Leaves alternate, simple, entire, linear, with revolute margins, with short petioles or petioles wanting. Capitula cyathiform, arranged in racemiform cymes (Fig. 1a); phyllaries in 34 rows, acute, with non-scarious margins. Receptacles flat, paleate; paleae folded, acute, with glandulose apices. Marginal florets female, sometimes with staminodes, in one row. Corolla bilabiate (Fig. 1b), with one adaxial and three abaxial lobes (very rarely pseudobilabiate, with one adaxial and four abaxial lobes), yellow. Disc florets perfect. Corolla tubular, sligthly zygomorphic, with straight epidermal-cell walls, without crystals, yellow; corolla lobes 5 , short, with the depth of the sinuses varying among them (Figs. 1c, 2c), without sclerenchymatous cells accompanying the submarginal narrow vascular strands. Stamen filaments without oxalate crystals; anthers shortly calcarate, with short, unbranched tails; endothecial tissue polarized; cells of filament collar wider than long. Style without star-shaped oxalate crystals, with obtuse sweeping-hairs not reaching the style branch bifurcation; style branches with obtuse, rounded apices, stigmatic areas in two apically confluent lines, style branch veins narrow. Cypselae (immature) cylindric to slightly obconic (Figs. 1b, 1c), ribbed, hairy, without conspicuous sclerenchymatic tissue, with small oxalate crystals of diverse shape (as "crystal sand") in the epidermis, without secretory ducts; carpopodium absent. Pappus of inconspicuous short scales (Fig. 1b, c; line drawing in Ortiz \& Paiva, 1995; Fig. 1).

\section{Other representative specimen examined}

ANGOLA. Huambo: Chianga, ca. 1700 m, 7-V-1967, M. Silva 2070 (LISC); $10 \mathrm{~km}$ from Cachiungo on the right side of the road Cachiungo-Bailundo, $1.5 \mathrm{~km}$ from the river Ko, ca. $1700 \mathrm{~m}, 23-\mathrm{VI}-$ 2007, S. Ortiz 847, J.A.R. Paiva, J. Rodríguez-Oubiña, R. Carballal, M. Serrano \& M. Soares (SANT).
The generic name honors Helder Cardoso, the first collector of this plant, and João Cardoso, who has accompanied us and provided invaluable help during our collecting trips in Angola.

\section{Discussion}

As a result of a molecular phylogenetic analysis using the cpDNA marker $n d b F$, Eldenäs \& al. (1999) suggested that Anisopappus should be assigned to Heliantheae s.l. instead of Inuleae as proposed by several authors in the last decade (Anderberg, 1991; Anderberg, 1994; Eldenäs \& Anderberg, 1996; Ortiz \& al., 1996; Eldenäs \& al., 1998). In that analysis Anisopappus forms a trichotomy with the Athroisma-Blepharispermum group and with the remaining genera of Heliantheae s.l. Panero \& Funk (2002), on the basis of a phylogenetic analysis of the entire Asteraceae family using a large number of chloroplast DNA markers, suggested that the group Athroisma-Blepharispermum, already found by Kim \& Jansen (1995) in their analysis of the Asteraceae using the marker $n d b \mathrm{~F}$, should be considered a tribe, which they denominate Athroismeae (including the genera Athroisma DC., Blepharispermum Wight ex DC., and Leucoblepharis Arn.), phylogenetically situated between a) a clade including the tribes Inuleae and Plucheeae - the latter currently included in Inuleae by its author (Anderberg \& Eldenäs, 2007; Anderberg, 2009) - and b) a large monophyletic group including the rest of subfamily Asteroideae (Heliantheae s.l.). A similar position for this tribe is also supported by the phylogenetic analyses of Panero \& Funk (2008). These authors had already noted the possibility of including Anisopappus in this tribe. Also recently Panero (2005) described the new subtribe Anisopappinae, with the sole genus Anisopappus, within the tribe Athroismeae. In 2007 Panero also included in Anisopappinae the genus Welwitschiella O. Hoffm. although more recently Anderberg (2009) removed this genus from the Athroismeae based on his preliminary molecular phylogenetic analyses which nested it within the tribe Astereae as was confirmed by Brouillet \& al. (2009). Cardosoa is very probably a member of that subtribe taking into account its morphological affinities to Anisopappus and we are currently carrying out a molecular phylogenetic analyses using the markers ITS and $n d b F$ to check the relationships of Cardosoa.

Differences in inflorescence morphology can be readily used to separate Cardosoa from its putative sister taxon Anisopappus. Cardosoa has racemiform cymes (Fig. 1a) whereas the genus Anisopappus, has corymbose or subcorymbose cymes (Fig. 1d), sometimes with capitula on long peduncles that appear 

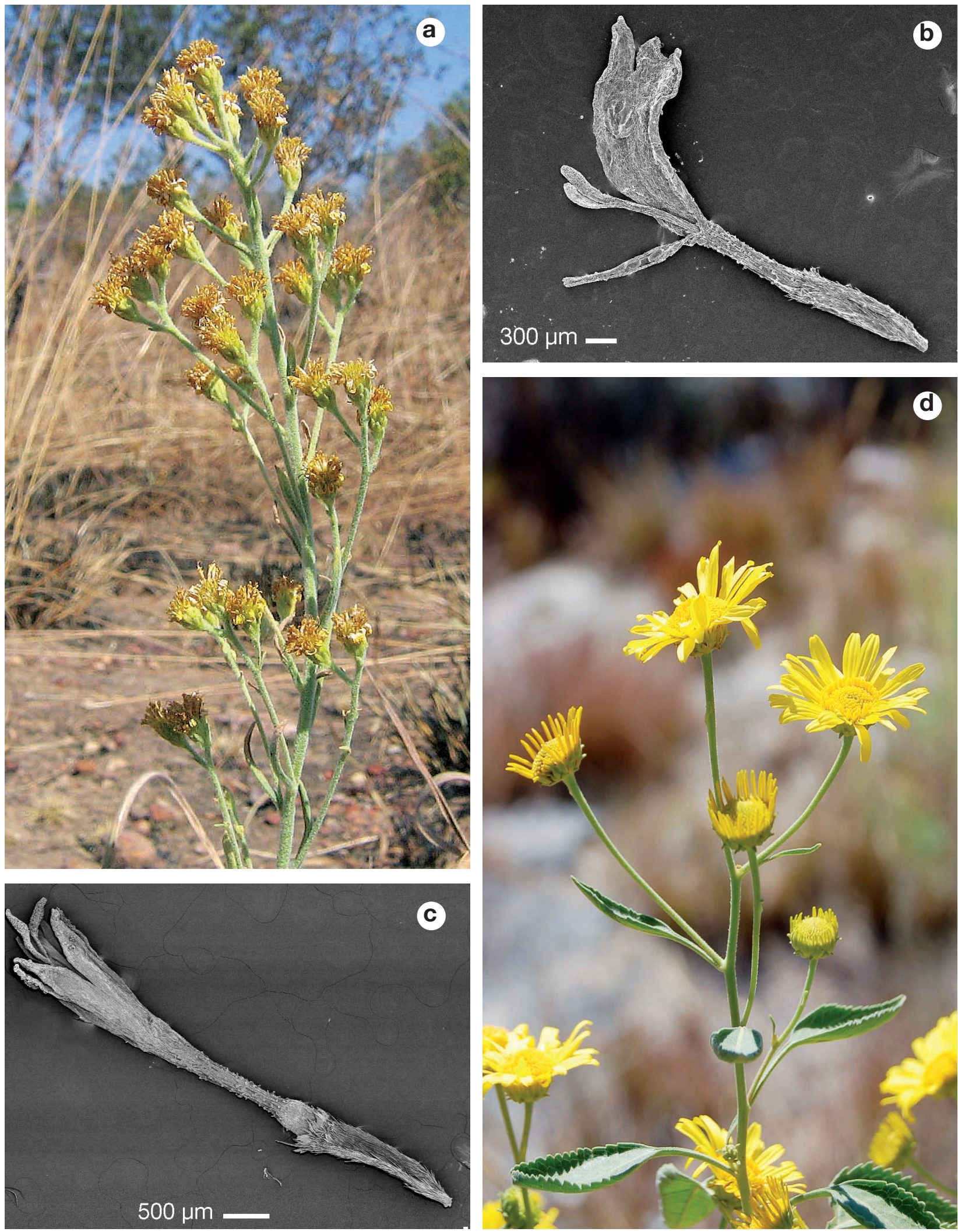

Fig. 1. Inflorescence (S. Ortiz 847, J.A.R. Paiva, J. Rodríguez-Oubiña, R. Carballal, M. Serrano \& M. Soares, SANT) and SEM micrographs of florets (M. Silva 2070, LISC) of Cardosoa athanasioides and inflorescence of Anisopappus fruticosus S. Ortiz \& Paiva (S. Ortiz 885, J.A.R. Paiva, J. Rodríguez-Oubiña, R. Carballal, M. Serrano \& M. Soares, SANT): a, inflorescence of C. athanasioides; b, marginal bilabiate floret of $C$. athanasioides; $\mathbf{c}$, disc floret of $C$. athanasioides, note the different depths of the lobe sinuses; $\mathbf{d}$, inflorescence of $A$. fruticosus. 


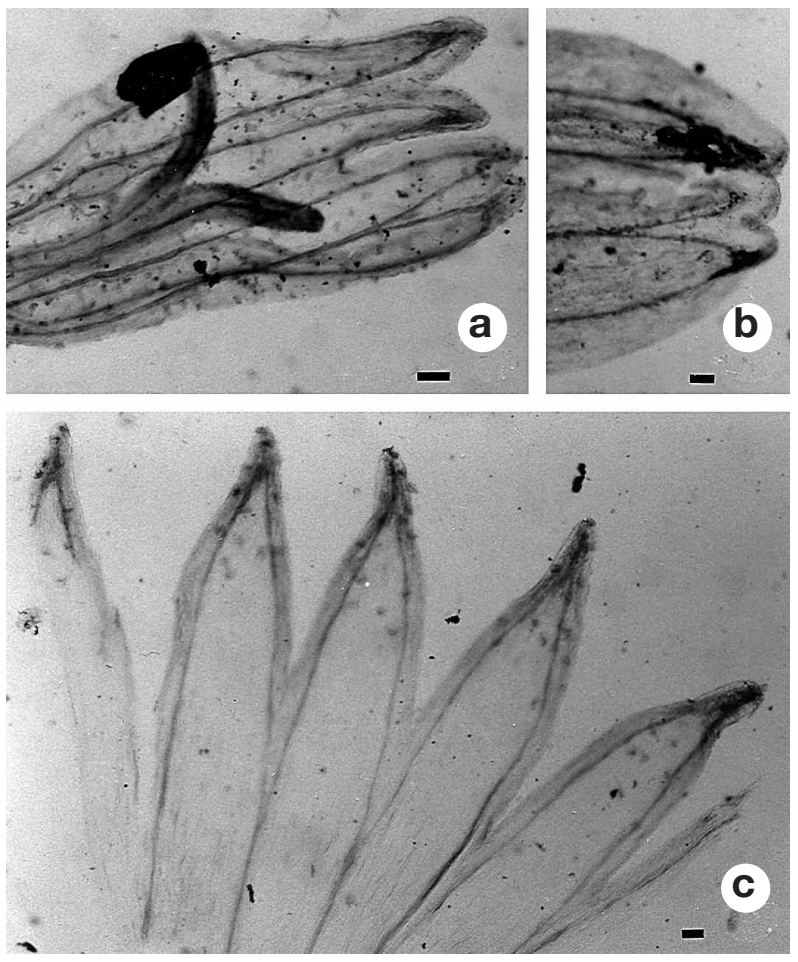

Fig. 2. Light microscopy photographs of florets of Cardosoa athanasioides (M. Silva 2070, LISC) and Anisopappus chinensis subsp. chinensis (B. Teixeira \& Andrade 8233, COI); a, lower lip of a ray floret of $C$. athanasioides showing the nerves of the apical lobes which remain separate to the base of the limb; $\mathbf{b}$, apex of a ray floret in $A$. chinensis where the nerves of the apical lobes join close to the sinuses; $\mathbf{c}$, corolla of a disc floret of $C$. athanasioides showing variation in the depth of the sinuses. Scale $=0.1 \mathrm{~mm}$.

solitary $[A$. chinensis Hook. \& Arn., A. grangeoides (Vatke \& Höpfner ex Klatt) Merxm., A. marianus Lawalrée, etc.].

The involucre of Cardosoa is cyathiform (Fig. 1a), whereas in Anisopappus it is campanulate to hemispheric (Fig. 1d). Only A. smutsii Hutch. and A. pseudopinnatifidus S. Ortiz \& Paiva have an involucre similar to that of Cardosoa.

The marginal florets of Cardosoa are bilabiate (one adaxial and three abaxial lobes) (Fig. 1b) or very rarely pseudobilabiate (one adaxial and four abaxial lobes), whereas the marginal florets of Anisopappus are always true ray florets (Fig. 1d). In addition, the marginal florets of Anisopappus are much larger than those of Cardosoa (abaxial limb 4-13 mm long in Anisopappus versus $1.5-2 \mathrm{~mm}$ long in Cardosoa), though in some species (such as $A$. pinnatifidus (Klatt) O. Hoffm., A. pseudopinnatifidus and A. chinensis subsp. scrophulariifolius (Baker) S. Ortiz, Paiva $\&$ Rodr. Oubiña) the ray florets may be absent. Cardosoa also differs from Anisopappus in the nerves of the apical lobes of the abaxial lip, which remain sepa- rate to the base of the limb (Fig. 2a), whereas in Anisopappus these nerves normally join close to the sinuses (Fig. 2b).

The disc florets of Cardosoa are zygomorphic, with the depth of the sinuses varying among lobes (Figs. 1c, 2c); in Anisopappus, by contrast, the disc florets are actinomorphic. In Cardosoa, the lobes are conspicuously more acuminate, with the nerve clearly extending to the apices (Fig. 2a); we have not observed this character in any of the species of Anisopappus.

The anthers of Cardosoa have a conspicuously apiculate apical appendage whereas in Anisopappus the apical appendage is acute, not apiculate.

The cypselae are not fully mature in the Cardosoa material available, but appear to differ markedly from those of Anisopappus, to judge from the number of nerves and incipient ribs: in Cardosoa the number of nerves per cypsela seems always to be less than or equal to 5 , and the number of ribs less than 10 , whereas in Anisopappus the number of nerves is characteristically 5-10(20?), and the number of ribs 10-20. The single exception to this is $A$. latifolius (S. Moore) B.L. Burtt, a distinctive species found to be sister to the other species of Anisopappus in the morphological cladistic analyses of Eldenäs \& Anderberg (1996).

\section{KeY to THE GENERA OF ANISOPAPPINAE (sensu Panero, 2007)}

1. Capitula disciform; receptacle epaleate; marginal florets generally tetramerous; pappus a crown of scales fused at the base Welwitschiella.

1. Capitula radiate or rarely discoid; receptacle paleate, rarely epaleate; marginal florets generally pentamerous; pappus of small \pm free scales or absent ....2

2. Capitula arranged in racemiform cymes; marginal florets bilabiate (rarely pseudobilabiate), with an abaxial limb 1.5-2 mm long and the nerves of the apical lobes separated to the base of the limb; disc florets more or less zygomorphic, sinuses depth varying among the lobes; apical appendage of the anther conspicuously apiculate; cypselae with up to 5 nerves and 10 ribs

Cardosoa

2. Capitula arranged on more or less lax corymbs; marginal florets true ray florets (rarely absent), with abaxial limb 4-12 mm long and nerves of the apical lobes joining close to the sinuses; disc florets totally actinomorphic; apical appendage of the anther not apiculate; cypselae with 5-10(20?) nerves and 10-20 ribs

Anisopappus

\section{Acknowledgements}

Our thanks go to Manuel Laínz for the Latin diagnosis, to Ramiro Barreiro for SEM micrographs, to G. Norman for the En- 
glish translation, to João Cardoso for his invaluable help during the collecting trips in Angola, and to the keepers of the herbaria mentioned for the loan of studied material.

\section{References}

Anderberg, A.A. 1991. Taxonomy and phylogeny of the tribe Inuleae (Asteraceae). Plant Systematics and Evolution 176: 75-123.

Anderberg, A.A. 1994. Tribe Inuleae. In: Bremer K. (ed.), Asteraceae. Cladistics \& Clasification: 273-291. Portland, Oregon, Timber Press.

Anderberg, A.A. 2009. Athroismeae. In: Funk., V.A., Susanna, A., Stuessy, T.F. \& Bayer, R.J. (eds.), Systematics Evolution and Biogeography of the Compositae: 681-688. IAPT, Vienna.

Anderberg, A.A. \& Eldenäs, P. 2007. Tribe Inuleae. In: Kadereit, J. W. \& Jeffrey, C. (eds.), The Families and Genera of Vascular Plants, vol. 8, Flowering Plants. Eudicots. Asterales: 374-391. Berlin, Springer.

Anderson, L.E. 1954. Hoyer's solution as a rapid mounting medium for bryophytes. Bryologist 57: 242-247.

Brouillet, L., Lowrey, T.K., Urbatsch, L., Karaman-Castro, V., Sancho, G., Wagstaff, S. \& Semple, J.C. 2009. Astereae. In: Funk., V.A., Susanna, A., Stuessy, T.F. \& Bayer, R.J. (eds.), Systematics Evolution and Biogeography of the Compositae: 589629. IAPT, Vienna.

Eldenäs, P. \& Anderberg, A.A. 1996. A cladistic analysis of Anisopappus (Asteraceae: Inuleae). Plant Systematics and Evolution 199: 167-192.

Eldenäs, P., Anderberg, A.A. \& Källersjö, M. 1998. Molecular phylogenetics of the tribe Inuleae s. str. (Asteraceae), based on
ITS sequences of nuclear ribosomal DNA. Plant Systematics and Evoution 210: 159-173.

Eldenäs, P., Källersjö, M. \& Anderberg, A.A. 1999. Phylogenetic placement and circumscription of tribes Inuleae s. str. and Plucheeae (Asteraceae): evidence from sequences of chloroplast gene ndhF. Molecular Phylogenetics and Evolution 13: 50-58.

Kim, H.-G. \& Jansen, R.K. 1995. ndhF sequence evolution and the major clades in the sunflower family. Proceedings of the Natural Academy of Sciences of the United States of America 92: 1037910383.

Ortiz, S. \& Paiva, J.A.R. 1995. Notes on African species of the genus Anisopappus Hook. \& Arn. (Asteraceae). Botanical Journal of the Linnaean Society 117: 39-46.

Ortiz, S., Paiva, J.A.R. \& Rodríguez-Oubiña, J. 1996. An outline of the genus Anisopappus Hook. \& Arn. (Compositae). Anales del Jardin Botánico de Madrid 54: 378-391.

Panero, J.L. 2005. New combinations and infrafamilial taxa in the Asteraceae. Phytologia 87(1): 1-14.

Panero, J.L. 2007. Tribe Athroismeae. In: Kadereit, J.W. \& Jeffrey, C. (eds.), The Families and Genera of Vascular Plants. Flowering Plants. Eudicots. Asterales 8: 395-400. Berlin, Springer.

Panero, J.L. \& Funk, V.A. 2002. Toward a phylogenetic subfamilial classification for the Compositae (Asteraceae). Proceedings of the Biological Society of Washington 115(4): 909-922.

Panero, J.L. \& Funk, V.A. 2008. The value of sampling anomalous taxa in phylogenetic studies: Major clades of the Asteraceae revealed. Molecular Phylogenetics and Evolution 47: 757-782.

Editor asociado: I. Álvarez Recibido: 28-VII-2009 Aceptado: 2-XI-2009 